International Journal of Linguistics and Translation Studies

Volume 2, Issue 3, 2021

Homepage: http://ijlts.org/index.php/ijlts/index

DOI: https://doi.org/10.36892/ijlts.v2i3.174

\title{
Women in Rap Songs: A Difference between Male and Female Voices
}

\author{
Genevieve D. Urbano \\ Roselyn Mae C. Balneg \\ Patricia Michaela C. \\ Collantes, Rafaela Reese M. Diaz \\ Jeahn Oliver D. Fernandez \\ Alyanna Nicole Q. Padilla \\ Margie Rose P. Sagadraca, \\ Juland D. Salayo \\ Senior High School, University of Santo Tomas \\ Manila, Philippines \\ jdsalayo@ust.edu.ph
}

\section{ARTICLE \\ HISTORY}

Received: $16 / 06 / 2021$

Accepted: $25 / 07 / 2021$

\section{KEYWORDS}

Original Pilipino

Music (OPM), lyric

analysis, women

empowerment, rap,

and women

\begin{abstract}
Hip-hop has become a male-dominated industry, and it has reached all over the world, including the Philippines. This study analyzed two Original Pilipino Music (OPM) rap songs: Neneng B by Nik Makino feat. Raf Davis, and Pantsu by Zae. The two songs were examined to see how women are represented and how women's empowerment is promoted. Addressing the objectives, this study used a qualitative design that involved stylistics and text analysis. Using the Feminist Theory and applying Sara Mills' Feminist Text analysis model, the lyrics were examined in a word, phrase/sentence, and discourse level. This research revealed that a female artist's song promotes woman empowerment while the song written by male artists has more objectification tendencies. This study further implicates the role and position of women in modern-day society with music.
\end{abstract}

\section{INTRODUCTION}

Studies on feminism is no longer novel in the area of research as several works of literature already established its relevance and implications especially in literary studies like a short story (Dials, 2017; Salayo \& Macam, 2018; Salayo \& Macam, 2020), poetry (Ika, \& Aditya, 2018; Suhadi, Baluqiah \& Mariansyah, 2017), novel (Fitriana, Tolla, Jasruddin \& Mahmudah, 2019), and other literary-based criticisms. The richness of literary research has further proved that literature serves as a tool and platform to shape women's empowerment, representation, and identity. This makes literature a "silent but powerful form of activism for women" (Dadawala, 2018, p. 131). From literary to performing arts, music and music videos are also considered tools in investigating the position and role of women in society, which further establish womenrelated issues on empowerment. However, behind the growing literature on this topic, there 
are also growing challenges concerning power, identity, and agency (Bretthauer et al., 2008; Rens, 2021; Hmouri, 2021). With the significant role of music in human development and growth (Welch et al., 2020), it is equally significant that investigations on feminism be continuously conducted to address women's continuing encounters and position in the contemporary period.

Music has been present since the start of the documented history of humanity (Levitin, 2006). Of the many influences on how people view men and women, media are the most pervasive and one of the most powerful. All forms of media communicate images of the sexes, many of which perpetuate unrealistic, stereotypical, and limiting perceptions. Women are underrepresented, which falsely implies that men are the cultural standard and women are unimportant or invisible (Wood, 1994). In 1979, a group of musicians, headed by Sylvia Robinson, released a song that introduced rap to the world. Rap became a subcategory of Hiphop, and 40 years later, it has become a multi-billion-dollar industry. She, then, was recognized as the "Mother of Hip-Hop." Despite being a woman as one of the proponents of Hip-hop/rap, women in this genre are not as recognized as men. Dennis (2018) suggests that Hip-hop is still a male-dominated industry. An analysis of rap and rock music from 1985-1990 discovered that rap contains more sexually explicit and graphic content about male domination compared with metal music. People challenged this circumstance and start to talk about women's individuality, diversity, and gender roles differently from the misogynistic perspective; however, it is still uncommon for women to be presented as independent, intelligent, or superior to men (Lee, 1999, cited in Weitzer \& Kubrin, 2009).

Dukes et al. (2019) researched the top 100 most popular songs from 1958-1998. Results show that in the 1990s, women and Black artists have recorded more hits. Over time, lyrics with love references performed by women decreased. From 1976 through 1984, lyrics with sex references peaked in this time when women used sexual references five times more than men. From 1991 to 1998, men used more sexual references compared to women. The song lyrics and their references have changed throughout the years. The change in the song themes affected the culture and the perspective of the listeners. The study of Fell and Sporleder (2014) showed that people could classify their genre through the lyrics of the songs. They said that the songs in the same genre have common words or lyrics. In classifying music, the rap genre is the easiest to know because of the lyrics alone. Rap lyrics have unique properties, like complex rhyme structures, longer lyrics, and distinctive vocabulary.

On the other hand, folk music is the most challenging genre, for it is quite the same as blues or country music. The top 100 words of blues and R\&B music are primarily about love and sex, while the top 100 words of rap music include many vulgar words. Additionally, the top 100 words of metal music are primarily about death and violence. The top 100 words of folk and country music are primarily about traveling and nature, while the top 100 words of reggae music are mainly in the Jamaican language. Lastly, the top 100 words of religious songs are about praising God. In their study, it concludes the difference in lyrics in each genre. Lyricsbased song classification has benefits such as music retrieval and seeing the trends in music.

According to Herd (2013), keywords such as alcohol, liquor, wealth, attraction, and drugs in rap songs are becoming more and more present. The negative attitude towards alcohol and the consequences of it in rap songs decreases. These were the results from the analysis of 
the 409 top-ranked rap music songs from the Billboard magazine charts released from 1979 through 2009. It was observed by Bértoli-Dutra (2014) in the multi-dimensional analysis of pop songs that the differences in meanings between North American and English pop song lyrics in regards to their language structure and vocabulary are primarily affected by culture, typical activities of people, and their experiences at the time. The study analyzed 6,290 individual songs released in Canada, the United Kingdom, and the United States of America from 1940 to 2009.

Further, a content analysis of 69 rap songs by Diamond, Bermudez, and Schensul (2009) showed that rave drugs, particularly ecstasy, were adapted to fit with rap artists' images and composed songs' various messages and moods. Drugs were perceived as something trendy among rap fans and audiences. Rap songs perpetuate racist stereotypes, depicting AfricanAmerican youth as heavy drug users, criminals, and sexual predators. Also, the excesses of sexual pursuit, alcohol, and drug use are depicted in gangster rap music and American popular music, rock, and country music genres. This kind of music depicts risky behaviors associated with the contents of the compositions and may have contributed to the desirability and normalization of ideas such as engaging in dangerous activities. The increasing audiences of rap music may contribute to the perception of the youth. Adverse effects and consequences of rap songs include depression, losing control of one's emotions, brain damage, and even death.

\subsection{Women's Image in Songs}

The analysis of the Billboard Top 20 in the United States showed that inclusions of themes like body objectification, gaze, attractiveness in music composition, the prevalence of objectification, and even self-objectification is present in popular songs. Genres like Rap and R\&B/Hip-Hop featured objectification of women more than other genres. Female artists also often objectify themselves more likely than male artists objectify themselves (Flynn et al., 2016). An assessment of 403 rap songs conducted by Weitzer and Kubrin (2009) suggested that rap music contributes to promoting women's inequality and empowerment of men. Its contents usually show women subordinate to men in various ways. However, according to their findings, most of the songs in their sample do not degrade women; some artists even challenged misogynistic messages and promoted a more egalitarian form of masculinity. While most rock and country songs present women as subordinate to men, rap songs present the intensity and graphic nature of their lyrical objectification of women. The researchers said that the absence of misogyny does not mean a positive representation of women. Most songs in their sample did not contain misogynistic lyrics, but they also presented women in a favorable perspective.

According to Apuke's (2019) study, Portrayal and Objectification of Women in Music Videos: A Review of Existing Studies, music videos of genres R\&B, hip hop, and pop contain more sexual objectification than country music videos. Female artists were more objectified and appeared to have an enticing behavior. Vulgar words and remarks about the objectification of women were frequently used. In their study, black male-produced music videos contain African-American women in revealing clothes and tend to give more importance to white skin, which leads them to conclude that race is an essential factor when music videos contain gender roles and sexual content. Also, Kusumaningrum and Suweleh's (2019) paper titled "Female and Male Gaze in Popular Songs: How Women (Really) Love Their Bodies" analyzed Meghan Trainor's "All About That Bass" and One Direction's "What Makes You Beautiful," two songs primarily attributed as promoting self-confidence and empowerment for women. The study 
aims to prove the male perspective within these songs by applying the male and female gaze by Mulvey (1989, cited in Kusumaningrum \& Suweleh, 2019) in analyzing the lyrical content. What had been found was that the songs essentially presented women as seen from the male perspective, subjected to the idea that they require men's approval and having the women's love of their bodies as a second-hand view.

\subsection{Research Problem}

This study aimed to analyze how women are viewed in popular songs. Specifically, this paper sought to answer the following questions:

1. How do male and female voices build women's image in an OPM rap song?

2. How do male and female perspectives differ in constructing woman's images in OPM rap songs?

3. How do OPM rap songs promote women's empowerment?

\section{Theoretical Framework}

This study employs the theory of feminism and the application of the stylistics analysis of Sara Mills. Accordingly, this theory strives to achieve equal rights for women. Additionally, this theory aims to challenge and change the patriarchal society and system and explain how gender systems work (England, 2001). Ideology can be defined as a text that is constructed together to form a concept. Maleševic, 2006 (cited in Al Duleimi \& Hussein, 2016, p. 22) stated that "ideology is not viewed as something imposed upon human beings, but rather as a functional necessity without which society cannot exist." In the theory of feminism, ideology aims to build a reliable method where ideas could be scientifically identified and strengthen the use of reason in governing issues about human affairs to better society (Eccleshal et al., 2003, cited in Al Duleimi \& Hussein, 2016). Maleševic's statement suggests that literature should be taken seriously, for it reflects society. Literature talks about what is morally right or wrong. It also tackles possible solutions to society's problems.

Feminism is considered an ideology by Tony Trew, a South African politician, and discourse analyst. Trew's assumption states that "the concepts in a discourse are related to a system, they are part of a theory or ideology, that is, a system of concepts and images which are a way of seeing and grasping things, and of interpreting what is seen or heard or read" (Fowler et al. 1979, cited in Al Duleimi \& Hussein, 2016, pp. 21-22). With this, feminists believe that women experience oppression and are subjected to personal and institutional discrimination. It is observable in texts in literature or media that women are often looked down on hence, the start of feminism movements.

\section{METHODS}

3.1. Research Design. To execute this study, the researchers used a qualitative research design and text-based analysis. According to Bhandari (2020), the qualitative method is the best way to understand and analyze non-numerical data, such as texts or lyrics. A qualitative design is used because the study focused on understanding lyrics and extracting their meaning. In analyzing and interpreting the lyrics, a stylistic approach will be utilized. Stylistics is the study of textual meaning. It focuses on the style and meaning of literary works (Jeffries, 2017). 
3.2. Study Corpora. The researchers have chosen two popular Original Pilipino Music (OPM) songs as the corpora of the present study, Neneng $B$ and Pantsu. These were taken from Azlrics.com and Youtube.com, September 2020. Azlrics.com is an online collection of lyrics from songs all around the world. Youtube.com is an online videosharing platform where anyone can upload videos anytime and anywhere (GFCLearnFree.org, n.d.).

Neneng $B$ is a hip-hop/ rap song released in 2019 by Artist Nik (Nikolson) Makino featuring Raf Davis and written with Elia Samuel Fedele for his album 'Now I Know.' The official music video for Neneng $B$ has accumulated 19,616,238 views on YouTube as of September 11,2020, even after it was taken down due to copyright claims made by Europe-based music producer Roko Tensei (Aseoch, 2020). The line "S-A-MP-I-N-T-O" suggests that "Neneng B" refers to a fictional female character in the Philippine gag show. A Filipino actress, who played Neneng B, is a character with many suitors who used pick-up lines to get her attention. The pick-up lines are usually in the form of a question where one is expected to answer "why" or "bakit." For that reason, her name became Neneng $B$ which means Neneng Bakit.

Table 1.

Study Corpora's Summary of Details

\begin{tabular}{|c|c|c|c|c|c|}
\hline Title & Genre & Singer & Composer & $\begin{array}{c}\text { Year } \\
\text { released }\end{array}$ & $\begin{array}{c}\text { Official music video } \\
\text { streams uploaded on } \\
\text { YouTube* }\end{array}$ \\
\hline $\begin{array}{l}\text { Neneng } \\
\text { B }\end{array}$ & $\begin{array}{l}\text { Hip- } \\
\text { Hop/Rap } \\
\text { (OPM) }\end{array}$ & $\begin{array}{l}\text { Nik Makino } \\
\text { ft. Raf Davis } \\
\text { (Male) }\end{array}$ & $\begin{array}{l}\text { Raf Davis, Nik } \\
\text { Makino, Elia } \\
\text { Samuel Fedele }\end{array}$ & 2019 & $\begin{array}{l}19,000,000 \\
\text { (As of September } \\
2020 \text { ) }\end{array}$ \\
\hline Pantsu & $\begin{array}{l}\text { Pop, } \\
\text { Hip- } \\
\text { Hop/Rap } \\
\text { (OPM) }\end{array}$ & $\begin{array}{l}\text { Zae } \\
\text { (Female) }\end{array}$ & Zae & 2019 & $\begin{array}{l}150,000 \text { views } \\
\text { (As of September } \\
2020)\end{array}$ \\
\hline
\end{tabular}

*Makino, 2019; Zararias, 2019

Concerned Artists of the Philippines (CAP), a musical organization founded in the Philippines, said that Nik Makino's Neneng B "reinforces the concept that girls exist to be fetishized for male pleasure" (ABS-CBN News, 2020, para. 6). They also reinforced that "art should be liberating, and not oppressive" (ABS-CBN News, 2020, para. 7) and urged young musicians to be mindful of their lyrics in their songs, for it may contribute to toxic and fragile masculinity.

Pantsu, a Hip-hop/ rap song released in 2019, was performed and written by Zae, a young rising female rapper. It was produced by \$NPRD and released under LOCAL, a community and platform that promotes local music from underground artists (UDoU.com, 2020). The music video was uploaded on Youtube on November 23, 2019, and it has accumulated more than 150,000 views as of September 2020. Pantsu (パンツ; pronounced 
as pantsu) is a Japanese term meaning panties or underwear. The pantsu theme became popular in the anime genre and manga because of its obscenity regardless of the minimal presence of nudity. It originated from the word Panchira (パンチ), which means "glimpse of panty." The rise of underwear fashion has risen to the western world, most possibly because of the photograph of Marilyn Monroe with her lifted dress showing her undergarments (Pantsu King, n.d.).

According to a media and entertainment blog, UdoU.com (2019), this song discusses women's liberation and society's perception towards women and their bodies. It is specifically an anti-misogynist rap that serves as a protest to those who objectify and slut-shame women. Moreover, it counterattacks the view towards women in the song Neneng B by Nik Makino that became the talk of the town due to its stolen beat and objectifying lyrics.

The researchers utilized Azlrics.com and Youtube.com to gather data as these are helpful in finding accurate lyrics of the songs. With these tools, the researchers could gather findings in line with content analysis. This helped the researchers compare songs by female and male artists, which contain different views on women. This also helped analyze the difference between how women are portrayed in songs by female and male artists.

In choosing the songs to be examined, the nationality, gender of the artist, year of release, and the number of streams were considered. Nik Makino and Raf Davis are male artists, while Zae Zacarias is a female artist based in the Philippines. The chosen songs were released in 2019. The released music videos of the songs uploaded on Youtube have surpassed more than 150,000 views. The factors considered in choosing the songs gave the study an accurate comparison.

3.3.Data Analysis. In this section, the researchers discussed the analysis and interpretation of the qualitative data collected to answer the research problems. The researchers analyzed the data by examining the lyrics using the Feminist text analysis of Sara Mills (1995, cited in Duleimi \& Hussein, 2016).

The model of feminism presented by Mills (1995), cited in Duleimi and Hussein, (2016) includes:

(a) Analysis at the Word Level. This part examines individual words and identifies gender-biased terms. This also examines the usage of sex-specific pronouns, misuse of generics, address terms, and the negative characterization of females in text.

(b) Analysis at Phrase/ Sentence Level. This analysis examines sentences and phrases concerning the context, history, and background knowledge. To do this analysis, a historical background is needed to see the connection and meaning of the text.

(c) Analysis at the Discourse Level. This level of analysis focuses on the meaning of the texts beyond the surface level or definition of the words used. This part aims to extract meanings from the text in connection with its context and background. It is very much concerned with how the texts are constructed together to form a meaning.

\section{RESULTS AND DISCUSSION}


4.1. The Description of Women in OPM Rap Song composed by a Female Artist

4.1.1. Analysis at Word Level

Sex-specific Pronouns

These are pronouns where the masculine forms can be used as a gender-neutral term to refer to individuals. The masculine form is seen as a standard that can cover both sexes while also referring to males. However, there is only one instance where a pronoun is used throughout the song, as the song mainly uses first and second-person pronouns. Rather than being specific for either sex, the song uses the pronoun "kanila" (their), which is gender-neutral like other pronouns in Filipino. The deliberate lack of gendered pronouns shows an inclusive focus in the song, not just referring to women or targeting men alone, but rather a collective range of people.

\title{
Generic Nouns
}

\section{Nouns that use the male perspective to refer to both male and female.}

a. Boy. "Boy" can sometimes be used as a general term to refer to someone of either sex or gender in expressions, but it is typically used for younger males. The song uses a somewhat taunting manner to those the song aims to call out, who could be of either sex or gender, but mostly males. The word also has connotations of immaturity, which can be seen in the certain behaviors being called out in the song.

\section{Address Terms}

Forms of address that are used neutrally but are typically associated with males as the norm and females as the non-standard form require distinction.

a. Alpha Females. Alpha, in this context, refers to a dominant figure, which is typically visualized as male. While not unheard of, the term alpha female is not as commonly used as the alpha male, and the word "alpha" is usually seen on the more masculine side of the scale. A distinction is made to present that the alphas referred to are, in fact, on the feminine side.

Negative Characterization of Females

These are often diminutives used as endearment toward women or simply derogatory terms heavily associated with them in a negative light.

a. Bitch. Originally the word bitch means "female dog (or foxes)" until during c. 1400, when people used it as a derogatory term for women (Online Etymology Dictionary, n.d.). In modern slang, bitch is an African-American vernacular, and it originated from male homosexuals regarding a man being sexually contemptuous. This slang became versatile because cis women and homosexuals reclaimed the word and used it as a word of endearment. However, the term bitch still suggests false power to women that challenge neither men nor patriarchy (Kleinman, Ezzel \& Frost, 2009).

\subsubsection{Analysis at Phrase/ Sentence Level}

Inference

\author{
a. "Neneng B, Maria Clara, o ano mang uri" (Neneng B, Maria Clara, or \\ anyone)
}

In this phrase, inference or drawing conclusions based on reasoning is used in analyzing it. In this case, it presents two kinds of women, which the artist used Neneng $B$ and Maria Clara to describe women. Maria Clara's image personified women during the colonization of Spaniards in the Philippines. During this period, women are obliged to follow different norms. Their outfits are floor-length and show little to no skin, 
except for their necks and faces. She is the heroine in Noli Me Tángere, a novel by a Filipino hero José Rizal, which heavily influenced women's Filipino ideals. The character represents the "Filipino ideal woman," who is innocent, pure, shy, and conservative.

On the other hand, the "Neneng $B$ " line is about a famous character in a Philippine famous gag show. Neneng $B$ is a woman who has many suitors. To court her, they use pick-up lines with a standard format that starts with a question that should be answered with "bakit" or why; hence, her name became Neneng Bakit or Neneng B in short. Based on her appearance and personality, she is a modernized and liberal woman because of her choice of outfits and personality. With these, people tend to fit women only into these two categories. Since Maria Clara is considered the "ideal," women like her are given more respect than liberate women like Neneng $B$.

Ready-made phrases

a. "Men are Trash."

The line "men are trash" came into being when Karabo Mokoena was murdered by her boyfriend, which started the hashtag of men's trash, and other women also shared their experiences related to this (Tanaka, 2019). The term is coined because the majority of women have experienced discrimination or disrespect from men. When this phrase is being said, it does not mean all men but enough men and instances to make women feel terrified. Moreover, women are being taught how to defend themselves by bringing pepper sprays, knives, alarms, etc., around men because of the increasing amount of hate crimes or abuse towards women.

\section{Simile}

A simile is a figure of speech that compares two things and uses terms such as "like" and "as," which is present in the song, Pantsu.

a. "Para kang asong ulol kamanyakan di makontrol" (You're like a wild dog that can't control itself)

b. "Your dick little like a minion"

In particular, "para kang asong ulol kamanyakan di makontrol" (You're like a wild dog that can't control itself) compares a man to a dog because animals, specifically mad dogs, usually have irrational actions. They do not have any self-control, which is similar to some people. This comparison is often presumed in society that men's lust or desire towards women cannot control. Their lack of self-control in controlling their lust is normalized, which causes harm or harassment towards women.

Another is "your dick is little like a minion," where the dick or penis is being compared to the size of a minion, which is presumed to be small. It is an insult to men because the size of the genitalia is one of the societal indicators of their masculinity.

\subsubsection{Analysis at Discourse Level}

The lyrics are analyzed with a more significant ideology through textual patterns and structure. The characterization of females in this song is mainly based on their personalities and attitude. It did not focus on women's appearance; instead, it focused on inviting women to speak out. The line "Neneng B, Maria Clara o ano mang uri" (Neneng B, Maria Clara, or anyone) shows inclusivity to all. Neneng B is a female 
character in a late-night show who is perceived as liberal because she wears modern clothes and has a louder personality.

On the other hand, Maria Clara is a female character in Jose Rizal's conservative novels and wears more traditional clothes and acts timid because Rizal's novels are set during the Spaniard colonization in the Philippines. The two female figures mentioned are viewed differently - one is less respected, while the latter is given more respect. In this song, the artist includes them both and is given the same amount of respect.
a. Ilabas ang mga panty. (Show off your panties)
b. Let this be our protest.
c. I-I'ma go and flaunt my body.
d. And still, bitch I'm fucking modest.

The lines aforementioned are part of the chorus repeated throughout the song; it depicts that the artist wants to emphasize these. This song targets to call out men and invites women to fight against misogyny. The lines,

a. Airheads be talking loudest

b. Slut-shaming to the highest

c. Feelin' like you are the dopest

d. I see, you been thirstin' on big booty videos

e. But the audacity to call us out when we show

f. Flawed culture, fuck misogyny

g. $\quad Y^{\prime}$ all disrespecting Neneng $B$

h. But what's wrong is in how you see

i. $\quad$ Para kang asong ulol (You're like a wild dog)

j. Kamanyakan di macontrol (Your lust can't be controlled)

k. Fuck your words and your opinion

l. Your dick little like a minion

m. Napipikon sa men are trash (You get offended with 'men are trash')

n. Pero sa kababaihan naman todo maka-bash (But you still continue to insult women),

are the counteract of the artist as a woman to the negative behavior men executed through the years.

\subsection{The Description of Women in OPM Rap Song composed by Male Artists}

\subsubsection{Analysis at Word Level}

\section{Sex-specific Nouns}

a. Man. Man is sometimes used as a general term to refer to someone of any sex or gender, but due to gender stereotype norms, this term is frequently associated with males. However, this word is used in the song as sex-specific due to the word "I'm." It also implies someone who utilizes toughness and confidence, in which males are perceived in the song.

b. Mister. The term mister is an English male honorific derived from the word master. The use of this title in the song connotes high regard to the male personas and superiority opposite to how the females are perceived.

\subsubsection{Negative Characterization of Females}


a. Bitch. Bitch refers to female dogs, foxes, wolves, and otters, but when associated with humans, it becomes derogatory. This term is used in the song to call out subordinate and unwanted females.

b. Chick. Chick, in the literal meaning, is a young, hatched bird. However, it has been considered (today) as diminutives to women in society. This term connotes how females are compared to small and delicate animals - below the males, in which females are portrayed in the song.

c. Sexy. The word sexy evokes sexual desire. Depending on the way it is used, it could connote malice or instill harmful intentions. This song is used alongside the words "mini-skirt at fake $\mathrm{C}$, implying a mere fancy.

\subsubsection{Analysis at Phrase/ Sentence Level}

Inference

a. "Call me "Mister Who's The Chick, Nik?" 'cause I got plenty."

b. "Napapakalmot na at napapaungol siya" (She is scratching (me) while moaning)

c. "Sabi niya "N-I-K (What?) Ibaon mo pa" (She said, "N-I-K (What?) Go deeper)

d. "Bilisan mo pa", (Do it faster)

e. $\quad$ "Sige, sige, sige pa" (Just continue)

The line "Call me" Mister Who's The Chick, Nik" 'cause I got plenty" indicates that the male claims that he is a womanizer and is often seen with several different women. The whole verse describes the male point of view before and during sexual intercourse. The words "napakalmot,"(scratched) "napaungol,(moaned) and phrases like "Ibaon mo pa,"(Go deeper) "Bilisan mo pa,"(Do it faster) "Sige, sige, sige pa" (Just continue) are used to imply that they are having sexual intercourse and these words and phrases are what women often say to him.

\section{Metaphor}

a. "Rosas ka ba? Kasi sa spaceship, isasakay kita" (Are you a rose? Because I will ride you in the spaceship)

b. "Uling ka ba, Kasi kanina sa'kin nagbabaga ka. (Are you a coal? Because you're turning me on)

c. "Sorbetes ka ba, Kasi gusto mong dinidilaan ka." (Are you an ice cream? Because you like it when I lick you)

d. "Palay ka ba, Kasi gusto mong binabayo kita." (Are you a grain? Because you like it when I pound you)

e. "Chicharon ka ba, Kasi ang ingay mo 'pag kinakain ka" (Are you a pork crackling? Because you are loud when I eat you out)

In the line, "Rosas ka ba? Kasi sa spaceship, isasakay kita", (Are you a rose? Because I will ride you in the spaceship) "rosas" or rose is a flower and often used to refer to a vagina or as a female sexual metaphor while the spaceship is used to refer to the male sexual organ or genitals. This line from the song talks about sexual intercourse or penetrating the vagina. In one verse, the woman is sexually compared to many 
different inanimate objects and is used in several sexual innuendos. This promotes direct sexual objectification. The song elaborates on women's sexuality in a degrading manner.

\subsubsection{Analysis at the Discourse Level}

Character. Women's identity is described as someone subordinate to men, someone who exists to satisfy the sexual desires of men. This implies that women are in it for sex when the whole point of the song is to sexualize and objectify women through pick-up lines and figures of speech. The lyrics are very descriptive in terms of sexualizing women or simply describing the woman's body. The lines

a. $\quad T$-shirt niya at pants ay black ta's pink na panty (She wore a pink panty with her black T-shirt and pants)

b. $\quad$ Parang Neneng $B$ ang kaniyang katawan (Her body is like Neneng B's)

c. $\quad$ Flat na petite na medyo makulit (She has a flat chest and petite body with a naughty personality)

d. Mahaba ang buhok at mga mata'y singkit (She has long hair and narrow eyes)

e. $\quad$ Siya ay sobrang sexy, mini-skirt at fake $C$ (She looks sexy wearing mini-skirt and fake $\mathrm{C}$ )

The use of figures of speech to produce explicit imagery was visible enough to express sexual objectification.

Fragmentation. The artist/men intend what the woman wants during the intercourse by associating them with different inanimate objects.

Palay ka ba? (bakit, bakit) Kasi gusto mong binabayo kita (huh) (Are you a grain? (Why?) Because you like it when I pound you)

Chicharon ka ba? (bakit, bakit) Kasi ang ingay mo 'pag kinakain ka (Are you a pork

crackling? (Why?) Because you are loud when I eat you out)

The woman in comparison to grain and chicharon, whereas these objects are being pounded and eaten.

Focalization. The artist himself described the body of the woman and how he was in awe by fetishizing her.

Chicks mga tigang, lahat ay wanna bang (The girls are horny, and they all want to hook up with me)

After one night stand, still, they wanna hang

The first line evokes how women are thirsty and lustful. Meanwhile, the external and internal focalizer presents the past and present about what happened during and after the one-night stand. 
The overall meaning of the song is to invite women to have sex with him. The artist used negative terms and mostly used degrading phrases to express his sexual wants. Based on the lyrics, women are seen as sex objects only. Sexual objectification is evident in this verse.

Miss ko na bawat parte, 'wag ka na maginarte (I miss all of your body, please don't act up)

Ulo ko'y tigang, sa'yo nakaabang (I'm thirsty and my body is waiting for you) Chicks mga tigang, lahat ay wanna bang.... (The girls are horny, and they all want to hook up with me)

Tapping sa daan, bitch, yeah, I'm the man (Hooking up on the road, bitch, yeah, I'm the man)

where women are someone that feeds men's sexual fantasies and desires. The last part of this verse highlights how men or the artist intends to submit to them and boost their ego as a man.

In connection, a study by Smiler, Shewmaker, and Hearon (2017) shows that male performers were most likely to sing about sexual behavior that objectifies both females and males. It also suggests that rap music is the genre that has the highest tendency to reference sexual behaviors and least likely reference romance. The songs Neneng B by Nik Makino and Raf Davis show validation to their study for it is a rap song by male performers. The analyses of the song above implied strong references to the sexual behaviors of men towards women.

\subsection{The Difference of Women's Image in OPM Rap Songs Between Male and Female Artists}

4.3.1. This table shows the physical descriptions of women according to male and female artists. In Pantsu, the terms used to describe the female body are concerning personality and attitude. The adjectives majestic, hypnotizing, and modest are abstract qualities and generic. On the other hand, in Neneng $B$, the words that characterize a female body are more specific and literal. The word sexy was used twice, which is a negative description of females, Mills (1995, cited in Al Duleimi \& Hussein, 2016). The words fit, flat, petite, makulit (naughty), mahaba ang buhok (long hair), and singkit (almond-shaped eyes) are the specific adjectives he used to describe what an 'attractive' woman is.

\section{Table 2}

\section{Lyric Comparison}

\section{Pantsu by Zae (Female Artist) Neneng B by Nik Makino feat. Raf Davis (Male} Artist)

"Our body, it's majestic, hypnotizing, we know."

"I-I'ma go and flaunt my body and still bitch I'm fucking modest."
"Sa ganda ng iyong mata't ngiti, ako'y naaattract" (I am attracted with how beautiful your eyes and smile looks)

"S-A-M P-I-N-T-O, sobrang sexy, fit na fit 
yung flat na petite tapos medyo makulit, mahaba ang buhok at mga mata'y singkit yun ang aking tipo minsan 'pag wala nang fake" (She's so sexy and fit. She is flatchested and petite with a naughty personality. She has long hair with narrow eyes; that's my type if there are no fakes available.)

"Siya ay sobrang sexy, mini-skirt at fake C" (She's so sexy wearing mini skirt and fake C)

"Chick na always down, hindi ka magsisisi" (A girl that is always down and you'll never regret.)

"Boom, parang Neneng $B$ ang kaniyang katawan (katawan)" (Boom, her body is like Neneng B)

4.3.2. The table shows the difference in male and female artists' actions towards women. The female artist invites women to move. On the other hand, the male artist's actions towards women are more sexually explicit.

\section{Table 3}

Lyric Comparison

\begin{tabular}{|c|c|}
\hline $\begin{array}{c}\text { Pantsu by Zae } \\
\text { (Female Artist) }\end{array}$ & $\begin{array}{c}\text { Neneng B by Nik Makino feat. Raf Davis } \\
\text { (Male Artist) }\end{array}$ \\
\hline $\begin{array}{l}\text { "Ilabas ang mga panty (show off your } \\
\text { panties), let this be our protest." } \\
\text { "To my girls, I give out heart-shaped } \\
\text { kisses." } \\
\text { "It's the fucking season women have to } \\
\text { shout." }\end{array}$ & $\begin{array}{l}\text { "Ang sarap mong titigan (titigan)" (I love staring at } \\
\text { you) } \\
\text { "Kasi sa spaceship, isasakay kita" (I'll ride you in } \\
\text { the spaceship) } \\
\text { "Binaba ko sa sahig tapos siya ay nilamig yumakap } \\
\text { siya sa akin habang siya'y kinikilig" (I removed (her } \\
\text { clothes) and she hugged me while shivering) } \\
\text { "Napapakalmot na at napapaungol siya" (She's } \\
\text { scratching (me) while moaning) } \\
\text { "Kasi gusto mong dinidilaan ka" (Because you like } \\
\text { it when I lick you) } \\
\text { "Kasi gusto mong binabayo kita" (Because you like } \\
\text { it when I pound you) } \\
\text { "Safe kapag kasama, 'wag kang magtaka" (Don't } \\
\text { doubt, you're safe with me) } \\
\text { "Kasi gusto mo 'yung nilalamas ka" (Because you } \\
\text { like it when I touch your body) } \\
\text { "Ulo ko'y tigang, sa'yo nakaabang" (I'm thirsty and } \\
\text { my body is waiting for you) } \\
\text { "Kasi gusto mong sinasakyan kita" (Because you } \\
\text { like it when I ride you) }\end{array}$ \\
\hline
\end{tabular}


The tables above show that the song by male artists used more explicit language than a female artist's song. Neneng $B$ used obscene lyrics that imply women as sexual beings from the perspective of men. On the other hand, Pantsu also used explicit language, but most curse words (bitch, fuck) emphasize her statements. These results proved Monk-Turner \& Sylvertooth (2008) study, where it suggests that there are differences in the lyrics between the songs of female and male rappers. Their study reveals that male rappers were most likely to use profane language compared to female rappers.

\subsection{Rap songs as corpora for women empowerment}

According to the media and digital news website, TakePart.com, rappers are breaking barriers and uniting to show awareness through their music in the music industry. A lot of them of today brag about being with a woman and promote sexual abuse. Contrary to it, some convey different social issues concerning women and their conventional roles in society, upholding respect. These rappers are Tupac Shakur, Macklemore, Shad, and Queen Latifah (Mormann, 2015).

Rap songs are among the genres that feature sexual objectification, and it is often normalized, shaping the youth's perception as the audience rises in a male-dominated industry (Dennis, 2018). Though there may be many rap songs that highlight misogynistic language, few and counting songs promote women's rights and empowerment. Some perceive that "Neneng $B$ " glorifies women and their bodies, but it objectifies and sexualizes them when analyzed. The song talks about women through sexual innuendo and suggests that women submit to men only to boost their ego and satisfy their sexual desires, which is objectionable. Thus, in this song, none of the lyrics aimed to uplift women.

On the other hand, "Pantsu" uplifts women while correcting the misinterpretations that everything women do is for the male gaze. The analysis shows that the songs use lyrics that help to empower and embrace women's femininity. In connection, this validates the study by Kusumaningrum and Suweleh (2019) titled "Female and Male Gaze in Popular Songs: How Women (Really) Love Their Bodies." It was discussed that there are existing songs that encourage women to love their bodies as the phrase 'love yourself' became a prominent tagline. In this case, many lines in Pantsu boost women; an example is "I'ma go and flaunt my body, and still bitch I'm fucking modest," meaning, whatever women wear, they are still worthy of respect. It boosts women's self-confidence towards their bodies as it implies that showcasing their bodies does not equate to being indecent.

Along with these, the lines "Our body, its majestic, hypnotizing, we know" and "It's the fucking season women have to shout" encourage women to speak up about these types of issues where they are being objectified and not to let themselves be oppressed. Kusumaningrum and Suweleh (2019) state that songs are claiming to empower women, but when analyzed, it still degrades and objectifies them because the point of view of the songs is still male or gaze. Pantsu successfully empowers women without bringing down other women throughout the song. Although the female artist talked about women and their bodies, she became inclusive by using concrete and specific words. She sees women as someone more than their physical characteristics as she characterized women using abstract adjectives like majestic.

\section{CONCLUSION AND FURTHER RESEARCH}

Language in the media plays a vital role in society. It is a social phenomenon for linguistic behavior that expresses complex social meanings (Holmes, 1997). Investigating the feminist 
tendencies in OPM rap songs allows us to understand the meanings of the songs and their interpretations. The rap song by a female artist, Pantsu, promotes women's empowerment by inviting women to embrace their femininity and fight against sexism. The song is focused on uplifting all women and calling out men for their bad behavior. The rap song written by a male artist, Neneng $B$, has higher tendencies to objectify women. The song's point of view is from a male perspective, and women are seen as sex objects. The song compared women with food or activities that invoke pleasure in men. Both songs target women but in different ways. Pantsu invites women to stand out for themselves, while Neneng $B$ serves as an invitation for sexual activity. The description of women in Pantsu is more generic, while in Neneng B, it is more specific and focuses on a woman's specific body type.

Considering that there are limitations in the study's findings, the researchers would like to recommend that future researchers to do more song analysis that depicts women's role, identity, representation, and position. This will help them improve and give a more comprehensive perspective towards songs that describe women. As this study focused only on two songs, specifically on the rap genre, the researchers recommended studying the other OPM genres like pop and ballad. With this, future researchers would have an opportunity to explore and analyze data about women's perspectives in different genres in the music industry. The researchers recommended more samples for analysis along with the limited genre used in this study to establish feminist tendencies further. Through this, future researchers would be able to gather more interpretations to give improvements and deepen the content analysis of OPM rap songs.

Furthermore, this study analyzed two recently released songs within the same year. As language and views evolve and fluctuate over time, it is recommended for future researchers to investigate the changes that can be found between songs from different decades. It may open a way to further look at the trends over the years, from what is acceptable to the extremes, and how the time difference of OPM artists affects the content of their songs.

\section{REFERENCES}

ABS-CBN News. (2020, January 22). Pinoy artists explain what's wrong with 'toxic' songs Awit,' 'Neneng $B^{\prime} \quad$ https://news.abs-cbn.com/entertainment/01/23/20/pinoy-artistsexplain-whats-wrong-with-toxic-songs-awit-neneng-b

Al Duleimi A, \& Hussein, H. (2016). Investigating feminist tendency in Margaret Atwood's "The Handmaid's Tale" in terms of Sara Mills' Model. A feminist stylistic study. British Journal of English Linguistics, 4(3), 21-34.

Apuke, O.D. \& Jigem, L.G. (2019, June). Portrayal and objectification of women in music videos: A review of existing studies. TSU Journal of Communication and Media Studies, 2(1), 160-170.

Aseoche, T. (2019, November 18). Nik Makino's 'Neneng B' MV gets taken down after allegedly stealing the beat from an international artist. Retrieved from https://www.wheninmanila.com/nik-makino-neneng-b-allegedly-stolen-frominternational-artist-roko-tensei/

AZLyrics.com. (2019). Nik Makino - Neneng B [Lyrics]. https://www.azlyrics.com/lyrics/nikmakino/nenengb.html

Bértoli-Dutra, P. (2014). Chapter 2.2 multi-dimensional analysis of pop songs. Studies in Corpus Linguistics, 149-176. doi:10.1075/scl.60.05ber. 
Bhandari, P. (2020, July 30). An introduction to qualitative research. Retrieved from https://www.scribbr.com/methodology/qualitative-research/

Bretthauer M.S.B., Schindler Zimmerman, T. \& Banning, J.H. (2007) A Feminist analysis of popular music. Journal of Feminist Family Therapy, 18(4), 29-51, DOI: 10.1300/J086v18n04_02.

Dadawala, D. (2018). Literature as a means for women's empowerment. International Journal of Research and Analytical Reviews, 5(1). 130-132.

Dennis, R. (2018, May 26). The Women of Rap. VOA. https://learningenglish.voanews.com/a/women-of-hip-hop/4368262.html

Dials, J.G. (2017). Feminism in Philippine mainstream short stories in English. International Journal of Languages, Literature and Linguistics, 3(4), 181-188. DOI: 10.18178/ij1l1.2017.3.4.130.

Diamond, S., Bermudez, R., \& Schensul, J. (2006). What's the rap about ecstasy? Journal of Adolescent Research, 21(3), 269-298. DOI: 10.1177/0743558406287398

Dukes, R., Bisel, T., Borega, K., Lobato, E., \& Owens, M. (2019). Expressions of love, sex, and hurt in popular songs: A content analysis of all-time greatest hits. The Social Science Journal, 40(4), 643-650. DOI: 10.1016/S0362-3319(03)00075- 2.

England, P. (2001). Gender and feminist studies. International Encyclopedia of the Social \& Behavioral Science, 5910-5915. https://doi.org/10.1016/b0-08-043076-7/03956-5

Fell, M. \& Sporleder, C (2014). Lyrics-based analysis and classification of music. COLING 2014, the 25th International Conference on Computational Linguistics: Technical Papers, 620-631.

Fitriana, I., Tolla, A., Jasruddin \& Mahmudah (2019). The characteristics of women's image in a novel of Entrok by Okky Madasari: A study of literary criticism in ideological feminism. Journal of Language Teaching and Research, 10(6), 1318-1326. DOI: http://dx.doi.org/10.17507/jltr.1006.22.

Flynn, M., Craig, C.M., Anderson, C.N., \& Holody, K.J. (2016). Objectification in popular music lyrics: An examination of gender and genre differences. Sex Roles, 75(3-4), 164176. doi:10.1007/s11199-016-0592-3.

GFCLearnFree.org. (n.d.) YouTube: What is youTube? Retrieved from https://edu.gcfglobal.org/en/youtube/what-is-youtube/1/

Herd, D. (2013). Changes in the prevalence of alcohol in rap music lyrics 1979-2009. Substance Use \& Misuse, 49(3), 333-342. DOI: 10.3109/10826084.2013.840003.

Hmouri, Z. (2021). A Study of Moroccan University EFL Learners' Pragmatic Failure: The Case of Using Expressive Speech Acts . Studies in Pragmatics and Discourse Analysis, 2(1), 1-10. https://doi.org/10.48185/spda.v2i1.191

Holmes, J. (1997). Women, language and identity. Journal of Sociolinguistics, 1(2), 195-223. https://doi.org/10.1111/1467-9481.00012

Ika, M. \& Aditya, P. (2018). Representation of woman image in anthology of poetry "Poetry of Rahim" by the woman poet of five countries. KnE Social Sciences, 3(9), 588-594. https://doi.org/10.18502/kss.v3i9.2722.

Jeffries, L. (2017). Stylistics. obo in Literary and Critical Theory. DOI: 10.1093/obo/9780190221911-0048.

Kleinman, S., Ezzell, M., \& Frost, A. C. (2009). Reclaiming critical analysis: The social harms of "Bitch." Sociological Analysis, 47. 
https://www.jmu.edu/socanth/sociology/wm_library/Ezzell.Reclaiming_Critical_Anal ysis.pdf

Kusumaningrum, A.F., \& Suweleh, F. (2019). Female and male gaze in popular songs: How women (really) love their bodies [Conference Paper]. 14th International Conference on Language, Literature, Culture, and Education (ICLLCE), pp. 48-53. Kuala Lumpur, Malaysia.

Levitin, D. J. (2006). This is your brain on music: The science of a human obsession. Dutton, Penguin Random House LLC.

Makino, N. (2019, November 15). Nik Makino - NENENG B (feat. Raf Davis) (Official Video)(Prod. Roko Tensei). https://www.youtube.com/watch?v=UQaj7BMSwcU.

Monk-Turner, E., \& Sylvertooth, D. (2008). Rap music: Gender difference in derogatory use. American Communication Journal, 10(4), 1-12.

Mormann, N. (2015, August 25). Straight outta philogyny: Four rappers who empower

Online Etymology Dictionary (n.d.). bitch (n). www.etymonline.com. Retrieved 11 9, 2020, from https://www.etymonline.com/word/bitch.

Patsu King (2012). Pantsu. Available at Know Your Meme (https://knowyourmeme.com/memes /pantsu).

Rens S.E. (2021) Women's empowerment, agency and self-determination in Afrobeats music videos: A multimodal critical discourse analysis. Front. Sociol. 6:646899. DOI: 10.3389/fsoc.2021.646899.

Salayo, J.D. \& Lontoc-Macam, A. (2019). Exploring character delineation: A transitivity analysis of O. henry's “A Retrieved Reformation.” Asian Journal of English Language Studies, 7, 151-168.

Salayo, J.D. \& Lontoc-Macam, A. (2020). From fancy to feminist frenzy fight: An ideational grammatical metaphor of Charlotte Perkins Gilman's 'The Yellow Wallpaper.' Journal of Foreign Language Teaching and Translation Studies, 5(2), 39-64. DOI: 10.22034/EFL.2020.231889.1042.

Smiler, A. P., Shewmaker, J. W., \& Hearon, B. (2017). From "I Want To Hold Your Hand" to "Promiscuous": Sexual stereotypes in popular music lyrics, 1960-2008. Sexuality \& Culture, 21(4), 1083-1105. https://doi.org/10.1007/s12119-017-9437-7

Sporleder, C., \& Fell, M. (2014, August). Lyrics-based analysis and classification of music. Retrieved from https://www.aclweb.org/anthology/C14-1059/

Suhadi, A., Baluqiah, K., \& Mariansyah, Y (2017). A comparative analysis of feminist thought in poems of Maya Angelou and Audre Lordre [Conference Paper]. Advances in Social Science, Education and Humanities Research (ASSEHR), 82. Ninth International Conference on Applied Linguistics (CONAPLIN 9), 154-157.

Tanaka, S. (2019). MEN ARE TRASH. Sister Namibia, 31(3), 26-28.

UDOU Team. (2020, January 7). 'Pantsu' by Zae - An Anti-Misogynist Rap That We Need to Hear. UDOu PH. https://udou.ph/music/latest-drop/pantsu-by-zae-anti-misogynistrap/

Weitzer, R., \& Kubrin, C.E. (2009). Misogyny in rap music. Men and Masculinities, 12(1), 329. DOI:10.1177/1097184x08327696.

Welch GF, Biasutti M, MacRitchie J, McPherson, G.E. \& Himonides, E. (2020) Editorial: The impact of music on human development and well-being. Front. Psychol., 11. DOI: 10.3389/fpsyg.2020.01246 
women

through

music.

Retrieved

from

http://www.takepart.com/article/2015/08/25/five-rappers-who-empower-women

Wood, J. T. (1994). Gendered media: The influence of media on views of gender. https://pages.nyu.edu/jackson/causes.of.gender.inequality/Readings/Wood\%20\%20Gendered\%20Media\%20-\%2094.pdf.

Zacarias Z. (2019, November 23). Zae - Pantsu prod. \$NPRD (Official Music Video). YouTube. https://www.youtube.com/watch?v=XSO6rV-fjP0

\section{ABOUT THE AUTHORS}

Genevieve D. Urbano, Roselyn Mae C. Balneg, Patricia Michaela C. Collantes, Rafaela Reese M. Diaz, Jeahn Oliver D. Fernandez, Alyanna Nicole Q. Padilla, and Margie Rose P. Sagadraca graduated Senior High School from the University of Santo Tomas in Manila, Philippines. They belonged to the Music, Arts and Design (MAD) Track, with music as their area of specialization. Their research interests involve music education and language of music through stylistics studies and women's studies.

Juland Dayo Salayo teaches English and Research at the University of Santo Tomas Senior High School. He earned his Master in Educational Management from Polytechnic University of the Philippines. Currently, he is writing his dissertation in Critical Language Pedagogy for his PhD in English Language Education (ELE) at the Philippine Normal University - Manila. His research interests include Sociolinguistics, Second Language Writing, Critical Writing, Transitivity Analysis and Critical Language Pedagogy. 